\title{
Shedding light on denervation and transmyocardial laser revascularization
}

\author{
Keith A. Horvath, MD
}

See related article on page 712 .

From the Department of Cardiac and Thoracic Surgery, Northwestern Medical Faculty Foundation, Chicago, Ill.

Received for publication June 5, 2001; accepted for publication June 8, 2001

Address for reprints: Keith A. Horvath, MD, Department of Cardiac and Thoracic Surgery, Northwestern Medical Faculty Foundation, 201 E Huron Ave, 10-125, Chicago, IL 60611-3008.

J Thorac Cardiovasc Surg 2001;122:647-8

Copyright (C) 2001 by The American Association for Thoracic Surgery

$0022-5223 / 2001 \$ 35.00+0 \quad \mathbf{1 2 / 1 / 1 1 7 8 3 1}$

doi:10.1067/mtc.2001.117831

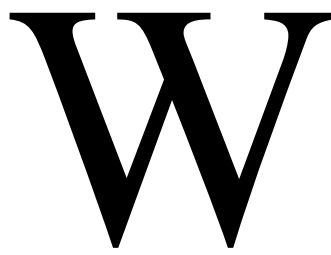

ith more than 6000 patients treated and with $70 \%$ to $75 \%$ of these patients having a significant improvement in their angina symptoms, one would think that the mechanism whereby transmyocardial laser revascularization (TMLR) achieves its effect would be well understood. Of the many possible mechanisms, including angiogenesis, channel patency, alterations of ventricular compliance, placebo effect, and denervation, it is the latter that is the most difficult to prove or disprove. Clinical studies have indirectly demonstrated that denervation does not play the primary role, a virtue of improvement in perfusion, as demonstrated by nuclear spec scans and positron emission tomograpic scans. ${ }^{1-5}$ Additionally, functional improvement with dobutamine stress echocardiography ${ }^{6}$ and cine magnetic resonance imaging ${ }^{7}$ also indicates that denervation is not the contributing mechanism. Furthermore, there is no significant increase in the number of acute myocardial infarctions postoperatively, despite a significant increase in exercise tolerance and activity levels.

In this issue, Minisi and associates ${ }^{8}$ have reported on an elegant set of experiments designed to evaluate the effect of TMLR on reflexes mediated by left ventricular receptors with sympathetic afferent fibers. Their results indicate that TMLR does not acutely interrupt the afferent nerves, which transmit the perception of anginal pain. These results are somewhat different from others that have been reported, and this is due to Minisi and colleagues' efforts to isolate the reflex responses by using an animal preparation with sinoaortic denervation and vagotomy. As a result, they were also able to demonstrate that the reflex circuitry was completely intact after TMLR. However, as the authors note, a major limitation of this study is that these results are from normal canine myocardium and may not be applicable to ischemic myocardium in human subjects. It does demonstrate that the amount of damage inflicted by TMLR is not enough to denervate normal myocardium.

The question of the extent of laser-induced injury and the ensuing response is an important one. Recently, attempts to perform laser revascularization percutaneously with a catheter have met with mixed results. ${ }^{9-11}$ In fact, a placebo-controlled trial has demonstrated no benefit of percutaneous myocardial laser revascularization. ${ }^{11}$ The revascularization that can be achieved percutaneously is limited because of the delivery of the laser energy to a very thin layer of the subendocardium (2-3 $\mathrm{mm}$ ) and the difficulty with navigating the catheter within the ventricle to provide an adequate distribution of the laser treatment. One other factor that may play a role is the type of laser light that is used. Minisi and associates have used a holmium:YAG laser. This laser is delivered through a fiber, which is manually advanced through the myocardium. However, it is unknown whether the injury created is principally caused by a mechanical effect of the fiber or caused by laser ablation. In the beating heart it is impossible to ensure that a fiber pushed by hand is advancing behind the wave of laser ablation. It would therefore be of interest to perform further experiments, not only in an ischemic model but also using the fiber alone or using other types of laser light that are not dependent on fiber delivery (for example, carbon 
dioxide) to confirm their results and provide clinical correlation. This difference in laser light has become clinically apparent over the long term because those treated with a holmium:YAG laser have had a significant increase in angina over 3 years after treatment. ${ }^{11}$ In contrast, patients treated with carbon dioxide TMLR have continued angina relief over 5 years after treatment. ${ }^{13}$

Demonstrating that TMLR does not denervate the heart is an important piece of the mechanistic puzzle.

\section{References}

1. Frazier $\mathrm{OH}$, Cooley DA, Kadipasaoglu KA, Pehlivanoglu S, Lindenmeir M, Barasch E, et al. Myocardial revascularization with laser: preliminary findings. Circulation. 1995;92(Suppl):II-58-65.

2. Horvath KA, Mannting F, Cummings N, Shernan SK, Cohn LH. Transmyocardial laser revascularization: operative techniques and clinical results at two years. J Thorac Cardiovasc Surg. 1996;111:1047-53.

3. Horvath KA, Cohn LH, Cooley DA, Crew JR, Frazier OH, Griffith BP, et al. Transmyocardial laser revascularization: results of a multicenter trial with transmyocardial laser revascularization used as sole therapy for end-stage coronary artery disease. J Thorac Cardiovasc Surg. 1997;113:645-54.

4. Schofield PM, Sharples LD, Caine N, Burns S, Tait S, Wistow T, et al. Transmyocardial laser revascularization in patients with refractory angina: a randomized controlled trial. Lancet. 1999;353:51924.

5. Frazier OH, March RJ, Horvath KA. Transmyocardial revasculariza- tion with a carbon dioxide laser in patients with end-stage coronary artery disease. N Engl J Med. 1999;341:1021-8.

6. Donovan CL, Landolfo KP, Lowe JE, Clements F, Coleman RB, Ryan T. Improvement in inducible ischemia during dobutamine stress echocardiography after transmyocardial laser revascularization in patients with refractory angina pectoris. J Am Coll Cardiol. 1997;30:607-12.

7. Horvath KA, Kim RJ, Judd RM, Parker MA, Fullerton DA. Contrast enhanced MRI assessment of microinfarction after transmyocardial laser revascularization. Circulation. 2000;102(Suppl):II-765.

8. Minisi AJ, Topaz O, Quinn MS, Mohanty LB. Cardiac nociceptive reflexes after transmyocardial laser revascularization: implications for the neural hypothesis of angina relief. $J$ Thorac Cardiovasc Surg. 2001;122:712-9.

9. Oesterle SN, Sanborn TA, Ali N, Resar J, Ramee SR, Heuser R, et al. Percutaneous transmyocardial laser revascularization for severe angina: the PACIFIC randomized trial. Lancet. 2000;356:1705-10.

10. Stone GW, Rubinstein P, Schmidt D, Kosinski EJ, Mishkel G, Teirstein PS. A prospective, randomized, multicenter trial of percutaneous transmyocardial laser revascularization in patients with nonrecanalizable chronic total occlusions. Circulation. 2000;102(Suppl): II-689.

11. Leon MB, Baim DS, Moses JW, Laham RJ, Knopf W, Reisman M, et al. A randomized blinded clinical trial comparing percutaneous laser myocardial revascularization (using Biosense LV mapping) vs placebo in patients with refractory coronary ischemia. Circulation. 2000;102(Suppl):II-565.

12. De Carlo M, Milano AD, Pratali S, Levantino M, Mariotti R, Bortolotti U. Symptomatic improvement after transmyocardial laser revascularization: How long does it last? Ann Thorac Surg. 2000;70:1130-3.

13. Horvath KA, Aranki SA, Cohn LH, Frazier OH, Kadipasaoglu KA, Boyce SW, et al. Sustained angina relief five years after transmyocardial revascularization with a $\mathrm{CO}_{2}$ laser. Circulation. 2000;102(Suppl):II-764. 